\section{Quality of Family Life and Workplace Deviant Behaviour with Perceived Competence as a Mediator among University Staff}

\author{
Dare A. Fagbenro \\ Obafemi Awolowo University, Department of Psychology, Osun State, Nigeria \\ dareinui2008@yahoo.com
}

\section{Mathew 0. Olasupo}

Obafemi Awolowo University, Department of Psychology, Osun State, Nigeria gbenga.olasupo@oauife.edu.ng

\begin{abstract}
Several studies have found a variety of factors as antecedents of deviant behaviour but the role of family life on workplace deviant behaviour, as well as the mediating role of perceived competence in the quality of family lifedeviant behaviour relationship, have received little study. This study examines the mediating effect of perceived competence on the relationship between the quality of family life and work-deviant behaviour. The study adopted the wellness model and self-determination theory as theoretical standpoints. Three hundred and eight-four (384) university staff in Nigeria participated in the study. Results revealed that there was a significant negative relationship between the quality of family life and workplace deviant behaviour. The result of the hierarchical multiple regression also revealed that perceived competence mediates the link between the quality of family life and workplace deviant behaviour. These findings suggest that psychologists should design training programmes aimed at improving the sense of competence and quality of family life, which invariably will reduce workplace deviant behaviour.
\end{abstract}

Keywords: quality of family life, perceived competence, workplace deviant behaviour, university employees

\section{Introduction}

Workplace deviant behaviour has continued to be a source of concern among psychologists and relevant stakeholders all over the world. This is because of the negative outcome this illicit behavior has both on organisational growth and employee well-being (Saad, Yahya, \& Yean, 2016; Shamsudin, Subramaniam, \& Ibrahim, 2011). Robinson and Bennett (1995, p. 556) “defined deviant behaviour as voluntary behaviour of violation of organisational norms, and therefore disrupting workplace strategies, and values, by an individual or group of people which invariably jeopardize organisation wellness or its employees". According to Shamsudin, Subramaniam and Ibrahim (2011), deviant behaviour is an act perpetrated by the organisation's members which causes damage to co-workers, management and the organizational facilities/equipment. In the literature, these negative-oriented
ORIGINAL SCIENTIFIC PAPER

RECEIVED: APRIL 2020

REVISED: MAY 2020

ACCEPTED: MAY 2020

DOI: 10.2478/ngoe-2020-0008

UDK: $316.36: 316.624: 378$

JEL: F13, D2, 011

Citation: Fagbenro, D.A., \& Olasupo, O. M. (2020). Quality of Family Life and Workplace Deviant Behaviour with Perceived Competence as a Mediator among University Staff. Naše gospodarstvo/Our Economy, 66(2), 15-27. DOI: 10.2478/ngoe-2020-0008

\section{NG OE}

NAŠE GOSPODARSTVO OUR ECONOMY

\begin{tabular}{l|l|l|} 
Vol. 66 & No. 2 & 2020 \\
\hline
\end{tabular}

pp. $15-27$ 
behaviours have been labelled by a variety of terms such as organisational misbehaviour, counterproductive work behaviour, dysfunctional behaviour, antisocial organisational behaviour, organisational deviance, and employee withdrawal (Everton, Jolton, \& Mastrangelo, 2007). This deviant behaviour could occur either at an interpersonal and/ or organisational level (Robinson \& Bennett, 1995). "Interpersonal deviance includes deviance showed to colleagues, co-workers and subordinate in the workplace (Fagbohungbe, Akinbode, \& Ayodeji 2012, p. 209) which may include acts that range from verbal abuse, physical assault (Robinson \& Bennett 1995, p. 565-566) as well as gossiping” (Robinson \& Bennett 1995, p. 562). Organisational deviance, on the other hand, includes deviant acts directed to the organisation, which are not limited to sabotage, theft, (Fagbohungbe, Akinbode, \& Ayodeji, 2012; Robinson \& Bennett, 1995), absenteeism (Robinson and Bennett, 1995), and tardiness (Fagbohungbe, Akinbode, \& Ayodeji, 2012). These two types of deviant behaviour-organisational and interpersonal-can also occur simultaneously, singly, or sequentially (Fagbohungbe, Akinbode, \& Ayodeji, 2012).

Roy-Bastounis and Minibas-Poussard (2012, p.1342) "asserted that work deviant behaviour harmed the organisation because this illicit behaviour directly affected organisational property and/or reduced employee effectiveness". Workplace deviant behaviour remains a serious issue, both in the developed world and in developing nations. In the United States, for example, Hollinger (2011) reported that nearly $45 \%$ of retailers attributed their inventory shortage to employee theft. In particular, employees' poor attitude toward work as a form of workplace deviance has been reported in public and private sector organisations (Suleiman, 2013). Further, some empirical studies have found that university employees engage in deviant or unethical work behaviours in Nigeria (Caroline, 2015; Moti, 2010), and Zimbabwe (Chirasha \& Mahapa, 2012). "The forms of deviant behaviours perpetuated by this set of employees included extortion of money, irregularity in examining students, abuse of office, sexual harassment, gross insubordination or disregard for constituted authority, employment racketeering, admission fraud and impersonation, distortion of staff records and manipulation of students' grades for financial gain” (Igbe, Okpa, \& Aniah 2017, p.74). This unacceptable behaviour contributes negatively to the growth and standard of the university system in the world, as well as in Nigeria. Due to these consequences, factors that could be responsible for deviant behaviour need to be investigated among university staff. To this end, some available studies have found factors such as job boredom (Chiamaka, Tochukwu, \& Kizito, 2015), job stress (Omar et al., 2011), and low job satisfaction (Balogun, Esan, Ezeugwu, \& Orifa, 2016; Omar et al., 2011), as predictors of deviant behaviour among employees in different types of organisations, but with little study of such factors as the quality of family life. For example, Chernyak-Hai, Kim, and Tziner (2019) studied marital status, but not exactly the quality of family life, as related to varieties of deviant behaviour performed in the workplace.

Zuna, Summers, Turnbull, and Hu (2012) define the quality of family life as a unique sense of subjective well-being within one's family, which is often informed by the degree to which family members and family-level desires are met. Quality of family life is also defined as the level of satisfactionor happiness with one's family well-being. The family is a vital and integral part of an individual's well-being. To achieve this well-being, an individual needs to pay adequate attention to family basic needs, as well as to put in constant effort to ensure harmony in family life by having a satisfactory personal life. It is also important to find ways of delivering excellent results with the limited resources at hand while maintaining a peaceful family life. Sometimes, having a satisfying family life seems challenging to employees with different personalities.

Krischer (2010) asserted that when employees have challenges in providing basic amenities or solving family issues, employees may resort to deviant behaviours by which they hope to gain some level of control over those situations. For instance, the inability of a university employee to manage challenges within the family can cause problems that often further contribute to poor satisfaction with one's family. In a bid to cope with these challenges, university employees sometimes engage in some form of deviant behaviour against the university out of a desire either to make their family happy or to escape from the challenges being faced in the family. Deviant behaviour like absenteeism, coming late to work or leaving work early, theft, and so on are behaviours that university employees may utilize to gain more time to focus on their quality of family life or to escape from the challenges that affect their family well-being. There have been some studies in the literature suggesting that conflict which is embedded in the quality of family life can contribute to negative work attitudes and behaviours (Shakir \& Siddiqui, 2014; Kinnunen, Geurts, \& Mauno, 2004; Ajala, 2017). While these outcomes are very pertinent for organisational effectiveness, there remains a need to examine the role of quality of life on workplace deviant behaviour.

Little is still known about the mechanism by which quality of family life influences work deviant behaviour. Studies have revealed that employees who have a high sense of competence manifest organisationally relevant work outcomes such as effective performance, acceptable behaviour and contributions to organisational goals (Dutcher \& Adams, 1994; Laschinger, Wong, McMahon, \& Kaufmann, 1999). It can be inferred that employees who are not satisfied with their family life may see themselves as not contributing to family 
well-being, which invariably makes such employees engage in work-deviant behaviour. However, the few studies (Shakir \& Siddiqui, 2014; Rubab 2017; Dewanga \& Verghese, 2018) that have investigated work-family conflict as an important component of family life paid little attention to the role of perceived competence as a mediator in the relationship.

This present study seeks to address the limitations of the extant literature by first, investigating the impact of the quality of family life on deviant behaviour and second, examine the mediating role of perceived competence on quality of life-workplace deviant behaviour, especially among a less-explored population (i.e., university employees) in a developing country, such as Nigeria. Studies on quality of life-workplace deviance link in an environment such as Nigeria are relatively scarce in the literature and thus this study significantly contributes to existing knowledge on the subject.The study investigates the indirect role of perceived competence in the relationship between the quality of family life and workplace deviant behaviour. The outcome of this study will contribute significantly to both theory and practice. Theoretically, the outcome of the study will lend support to, and also highlight the importance of, using a wellness model (Adams, Bezner \& Steinhardt, 1997) and self-determination theory through incorporating quality of family life and perceived competence as an important personal resource that can explain workplace deviant behaviour among employees in any economy of the world. In practice, the study will also broaden managerial knowledge about possible intervention programmes that would reduce or prevent workplace deviant behaviour among university employees. The study is divided into five sections: introduction, literature review, methodology, results and discussion.

\section{Literature Review}

\section{Quality of family life and workplace deviant behaviour}

Dewanga and Verghese (2018) examined the predictors of deviant workplace behaviour. The study established that family-to-work conflict predicts workplace deviant behaviour. Malisetty and Kumari (2016) examined work-family conflict, stress, organisational justice and deviant behaviour among a sample of 500 operational staff. The study found a significant positive connection between organisational justice, perceptions of work-family conflict, stress and deviant behaviour. Rubab (2017) examined the role of work-family conflict on burnout and workplace deviant behaviour of 250 employees. The finding revealed a positive relationship between work-family conflict and burnout and workplace deviant behaviour. Shakir and Siddiqui (2014) explored the association between work-life balance and deviant workplace behaviour. The study used 282 employees from several organisations in Karachi, Pakistan. The results showed that all dimensions of work-life balance except personal commitment have a significant influence on deviant workplace behaviour. The study found that family functioning has a significant influence on counterproductive work behaviour.

Radzali, Ahmad and Omar (2013) examined family-to-work conflict, workload, job stress and deviant workplace behaviour among 234 nurses in Malaysia hospitals. The result revealed a joint influence of family-to-work conflict, workload and job stress on deviance behaviour. Furthermore, the study also showed that family-to-work conflict independently predict workplace behaviour. Also, Bennett and Amyx (2013) investigated the influence of work-family conflict on job deviance among 234 respondents. The result revealed that increased work and family role divergence negatively influenced job deviance and contributed significantly to high deviant workplace behaviour. Ferguson, Carlson and Whitten (2012) examined the role played by work-family conflict and gender on production deviance. The result showed that work-to-family conflict positively influences production deviance. Ferguson (2012) examined the influence of family conflict on deviant behaviour among 344 participants. The result revealed that family conflict has an influence on work deviant behaviour.

Another study by Darrat (2010) empirically investigated the influence of family conflict on deviant behaviour among employees. The result showed a significant influence of family conflict on work deviant behaviour. The association between quality of life and workplace deviance was also supported by the Wellness Model (Adams, Bezner \& Steinhardt, 1997). This is because when employees is satisfied with their family wellness, such employees engage in behaviour that is not detrimental to the organisation; but in a situation where the wellness of a family is jeopardised, such employees would engage in deviant acts in an attempt to manage these challenges.

No research has yet investigated the influence of quality of family life on workplace deviant behaviour using data from university employees, especially in Nigeria, where workplace deviance seems to be highly prevalent (Fagbohungbe, Akinbode, \& Ayodeji, 2012; Olabimtan \& Alausa, 2014). This study hopes to overcome the constraints of earlier studies. Hence, we expect that:

Hypothesis 1: Quality of family life significantly and negatively relates to workplace deviant behaviour among university employees. 


\section{The mediating role of perceived competence in the quality of the family life-deviance relationship}

Competence has been conceptualised broadly by different scholars. According to Ratnasari and Adam (2019), competence is defined as the abilities required in the workplace; this refers to the expertise needed by each individual that will allow them to carry out their duties and responsibilities effectively and improve their professional quality standards at work. Balogun, Ojedokun and Tijani (2012) defined competence as a person's ability to successfully meet complex demands in a particular context through the use of both cognitive and non-cognitive aspects of problem-solving.

Boyatzis (2008) defined competence as a hidden attribute of an individual that is often linked to actual performance. Masterpasqua (2010) asserted that competence refers to versatile, psychological, passionate, behavioural and social characteristics which complement an individual's absolute or unrestricted beliefs and expectations about his/ her ability to perform those attributes. Thus, it can be said that having a sense of competence means the confidence of an individual that he of she has the abilities to master the work environment and the work itself.

White (2001) concluded that perceived self-competence refers to the belief that an individual has the necessary skills and ability to communicate and also manipulate the environment. Some individuals have the belief that they are competent in a variety of tasks, while some individuals do not believe that they are competent to handle tasks assigned.

A sense of competence at work may serve as an important buffer to predict how the employee will tackle issues and relate with other co-workers in the workplace. The employee who believes that they are not competent in the workplace tends not to have the personal resources to cope with this challenges of family commitment or is unable to meet family expectation or satisfaction which invariably could make the employee engage in deviant behaviour. According to Harter (1990), one way in which a person can perceive their competence level at work is through measures of their self-esteem.

The few available studies on perceived competence and workplace deviant behaviour have shown that employees with high competence engage in less destructive behaviour, such as workplace deviance. For instance, Abas, Omar, Halim and Hafidz (2015) examined the mediating role of organisational-based self-esteem in the relationship between perceived organisational support and counterproductive work behaviour among public service officers. Their study found that organisational-based self-esteem mediates the relationship between perceived organisational support and counterproductive work behaviour.

Ferris Brown, Lian, and Keeping (2009) also found that organisational-based self-esteem mediates the relationship between perceived organisational support and counterproductive work behaviour. Thau, Aquino, and Wittek (2007) found that workers who were uncertain about their competency level were more likely to be involved in antisocial work behaviour.

There is a scarcity of literature linking perceived competence to workplace deviant behaviour, but there are related studies on perceived competence and other constructs, such as job outcome. For instance, Manani and Ngui (2019) found that there is a significant positive effect of competence on employee job performance. Also, Li (2015) examined perceived competence and autonomy on subjective happiness. The results showed that employees' subjective happiness is influenced by both competence and autonomy factors.

From the tenets of self-determination theory (Deci \& Ryan, 1985), the employee who lacks self-determination might not have the prerequisite skill and knowledge to perform a certain task, which may influence such individuals to engage in negative behaviour. Research has also shown that a high sense of competence results in organisationally relevant work outcomes such as optimal individual and organisational performance (Dutcher \& Adams, 1994; Laschinger, Wong, McMahon, \& Kaufmann, 1999). Studies have also shown that employees who perceived that they have the skill and knowledge to engage in a task could enhance their sense of taking responsibility for their family well-being, which invariably makes them engage in positive work behaviour. However, when employees perceive low competence, this may lead to neglect of family well-being; this may, in turn, result in unacceptable behaviour, such as workplace deviant behaviour. Based on the pattern of relationships reported among quality of family life, perceived competence and workplace attitudes in the literature (Ulrich 1998; Wu 2010; Fadli, 2012), we expect that:

Hypothesis 2: Perceived competence significantly mediates the association between the quality of family life and workplace deviant behaviour among university employees.

This model proposes that when university staff manage their quality of family life well, they might not engage in workplace deviant behaviour. It is also expected that workplace deviant behaviour may be reduced when employees have high perceived competence, despite the low quality of family life. 


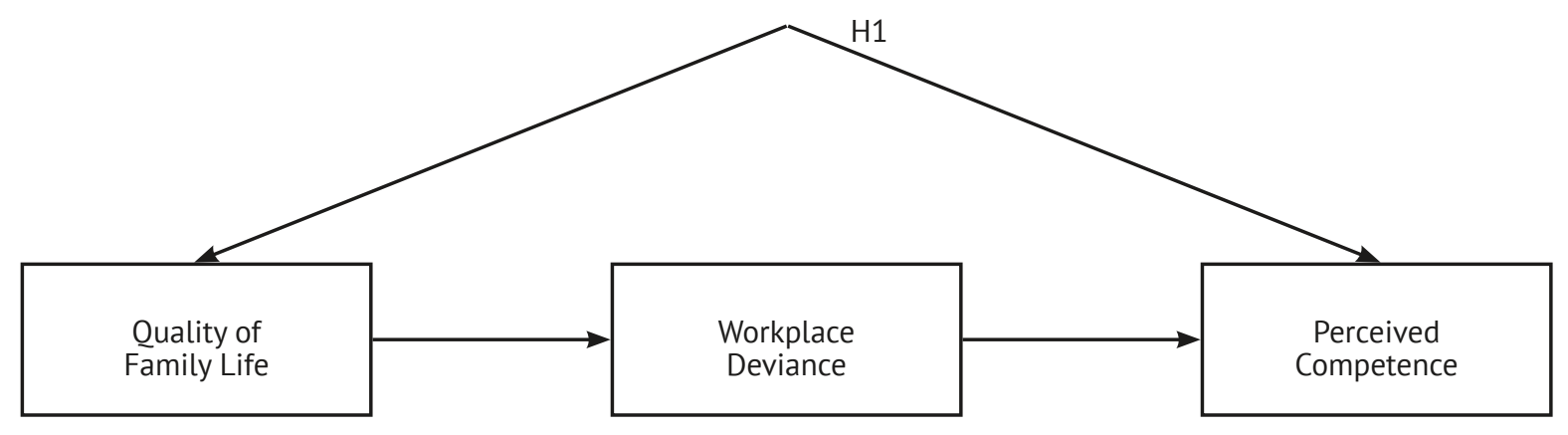

$\mathrm{H} 2$

\section{Methodology}

\section{Design and participants}

The study utilised a cross-sectional survey design. The predictor variable was quality of life while the criterion variable was workplace deviant behaviour. The mediating variable in this study was perceived competence. The 384 respondents who participated in the study were between 21 to 63 years old, with a median age of 48 years and a standard deviation of 9.26. Descriptive analysis of participants' gender revealed that 229 (59.6\%) were males and 155 (40.4\%) were females. In terms of religious affiliation, 234 (60.9\%) were Christians, 149 (33.9\%) were Muslims, while 1 (.3\%) was adherent of traditional religion. Respondents' educational background revealed that 19 (4.9\%) had completed only primary/secondary education; 37 (9.6\%) claimed they were NCE (Nigeria Certificate of Education)/OND (Ordinary National Diploma) holders, $123(32.0 \%)$ reported that they were B.Sc/HND holders, (Bachelor of Science /Higher National Diploma) holders, 59 (15.4\%) reported that they were M.Sc holders, while 146 (38.0\%) respondents claimed qualification at $\mathrm{PhD}$ level. The spread of participants in terms of marital status showed that 33 (8.6\%) were single, 279 (72.7\%) were married, 45 (11.7\%) were widowed while only 27 (7.0\%) were separated. Staff category revealed that 165 (43.0\%) were non-teaching staff while a majority, 219 (57.0\%) were teaching staff. Furthermore, the distribution of respondents by university category revealed that a majority of the participants 251(65.4\%) were from public universities while 133 (34.6\%) were from private universities. Lastly, the distribution of participants by length of service showed that 219 (57.0\%) had spent 1-10years in service, a majority 230 (59.9\%) of respondents had spent $11-20$ years, while 37 $(9.6 \%)$ had spent $1-5$ years as university employees.

\section{Population}

The population of the study was comprised of university employees working in Obafemi Awolowo University, University of Ibadan, Lead City University and Oduduwa University-all in SouthWest Nigeria.

\section{Measures}

Work Deviant Behaviour Scale: Workplace deviant behaviour was assessed with the 19- item Workplace Deviance scale developed by Bennett and Robinson (2000) named the "Interpersonal and Organisational Deviance Scale" by its authors. A sample item on this scale reads "Put little effort into your work” (Bennett \& Robinson, (2000), p.360). The participants' answers were scored on a 5-point scale ranging from 1 - never to 5 - daily. "The original authors of the scale required answers on a 7-point scale and they reported reliability of .81 for the Organisational deviance sub-scale and .78 for the Interpersonal deviance sub-scale” (Bennett \& Robinson, 2000, p. 354). In Nigeria, the scale has also been used by Olabimitan and Alausa (2014) where they reported reliability coefficients of .75 for the interpersonal deviance sub-scale and .77 for organisational workplace deviance among nurses in Lagos State University. In this study, the scale was validated usingconfirmatory factor analysis (CFA) and virtually all the items loaded significantly on their constructs $(\mathrm{p}<.001)$, with weights ranging from 0.45 to 0.87 . A Kaiser-Meyer-Olkin (KMO) of .90 indicated the sampling adequacy of the scale. The present study had a Cronbach coefficient of .97 for all 19 items. The high total score on all 19 items of the scale was intended to measure high workplace deviant behaviour while a low score meant low workplace deviant behaviour.

Quality of Family Life Scale: Quality of family life was captured using a 25-item Beach Center Family Scale 
(FQOL) described by Hu, Summers, Turnbull and Zuna (2011). A sample item of the scale reads "My family enjoys spending time together". The 5-point scale ranged from 1 for "very dissatisfied" to 5 for "very satisfied." In this study, the scale was validated with confirmatory factor analysis (CFA) and the items ranged from 0.50 to 0.84. A Kaiser-Meyer-Olkin (KMO) score of .89 indicated the sampling adequacy of the scale. Hu, Summers, Turnbull and Zuna (2011) reported a coefficient of .88 for the total scale. The coefficient Cronbach's alpha for this scale was .96. A high score means high quality of family life while a low score on the scale means a low quality of family life.

Perceived competence Scale: Perceived competence was captured using a 13-item perceived competence scale adapted and applied in Nigeria (Bajo, 2005; Balogun, Ojedokun, \& Tijani, 2012; Olasupo \& Fagbenro, 2018), but this scale was originally developed as a 23-item scale by Wagner and Morse (1975) and re-modified by Snyder and Morris (1978) to consist of 15 items only. Two sample items read "No one knows this job better than I do" (Wagner \& Morse, 1975, p.454) and "I honestly believe I have all the skills necessary to perform this task well” (Snyder \& Morris, 1978, p. 423; Wagner \& Morse, (1975), p. 454). A 5-point Likert format ranging from 1 = strongly Disagree to 5 = strongly agree was used to score the scale in the present study, as well as in the studies conducted by Balogun, Ojedokun and Tijani (2012), and by Olasupo and Fagbenro (2018), differing from the procedure suggested by Wagner and Morse (1975) to answer the items from -4 (very strong disagreement) to +4 (very strong agreement). Some items were reversed-scored on the scale. In Nigeria, Cronbach's alpha coefficient of .65 was reported, and the Split-half reliability coefficient of was .57 for the scale (Bajo, 2005; Balogun, Ojedokun, \& Tijani, (2012); Olasupo \& Fagbenro, (2018)). Balogun, Ojedokun and Tijani (2012) also reported a Cronbach's alpha coefficient of 0.72 among employees in a university teaching hospital in Nigeria. The present study validated this scale using a confirmatory factor analysis (CFA) with weights ranging from 0.47 to 0.88 for the items. A Kaiser-Meyer-Olkin (KMO) score of .70 indicated the sampling adequacy of the scale. Cronbach's alpha coefficient was .56 in this present study. Scores that are high above the mean reflect a high level of perceived competence, while a score below the mean represents low perceived competence.

\section{Procedure}

A questionnaire was used to collect data after the required permits were obtained from the management of the four universities. Thereafter, the researchers explained the purpose as well as the rationale for the study to the respondents. The researchers also assured the respondents that their responses would only be used for research purpose and any respondent could decide to withdraw from the study. The researchers adhered strictly to the ethical rules of research. Furthermore, respondents were approached in their various offices during the close of work, to avoid distracting these workers. The questionnaire distribution was carried out by the researchers, assisted by two research assistants who were trained on the techniques of proper data collection. The researchers sought the consent of the respondents by asking them to sign the informed consent form attached to the questionnaire. The questionnaires were distributed by the researchers to each participating university employee in their offices in their respective universities at different times. Most of the employees in the four universities used were so busy that only a few employees filled out their questionnaire on the spot while the majority of the respondents returned it at a later date. Twelve weeks were used for the data collection in the study. Using a purposive sampling technique, 100 copies of the questionnaire were distributed across the four universities, totalling about 400 questionnaires, while 10 of the questionnaires were not returned and 6 had incomplete responses, making only 384 questionnaires usable for data analysis, yielding a response rate of $96 \%$.

\section{Results}

\section{Hypothesis one}

The study used Pearson Correlation to test all the variables in this study and the analysis is presented in both Figure 2 and Table 1.

Figure 2 shows the direction and magnitude of correlations among the study variables. The blue colour indicates positive relationships while the red colour indicates negative relationships. The intensity of the colour shows the magnitude of relationships among the variables. The result, as shown in Table 1 revealed that there was a significant inverse relationship between the quality of family life and workplace deviant behaviour $[\mathrm{r}(382)=-.53$, $\mathrm{p}<.01]$. The result implies that as the quality of family life of university employee increases, the tendency to engage in workplace deviant behaviour decreases. There was a significant negative relationship between perceived competence and workplace deviance [ $\mathrm{r}(382)=-.25$, $\mathrm{p}<.01]$. This implies that as university staff's sense of competence increases, their tendency to engage in workplace deviance decreases. 
Figure 2. Correlogram of study variables

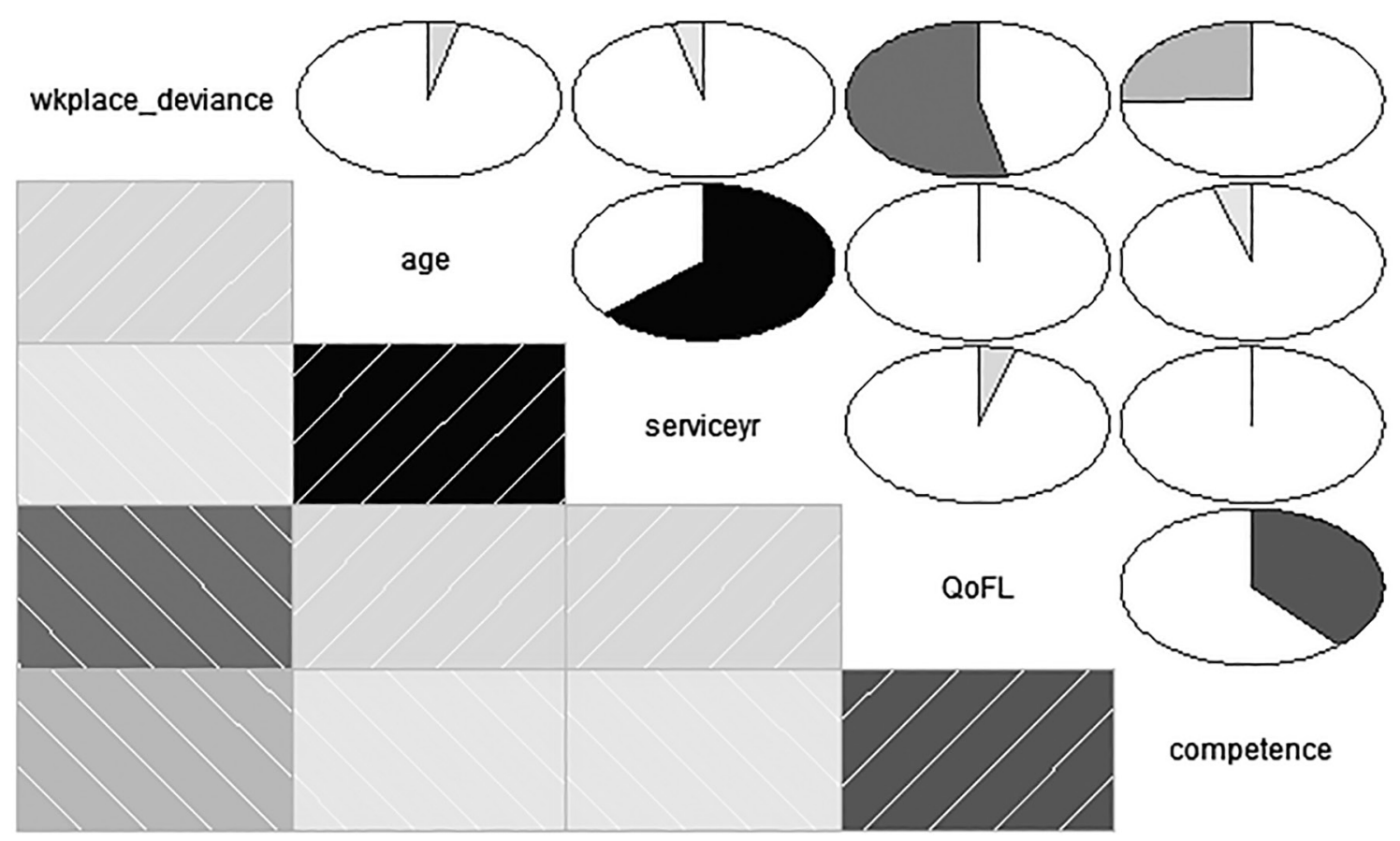

Note: wk_deviance $=$ Workplace deviant behaviour, serviceyr $=$ years in service, QoFL $=$ quality of family life, competence $=$ Perceived competence

Table 1. Pearson correlation matrix showing the mean, SD and variables relationship

\begin{tabular}{lccccccc} 
Variables & M & S.D & 1 & 2 & 3 & 4 & 5 \\
\hline 1. Age & 46.88 & 9.36 & 1 & $.63^{* *}$ & 0.00 & -0.04 & 0.03 \\
\hline 2. Years in service & 10.75 & 6.82 & & 1 & 0.04 & -0.00 & -0.04 \\
\hline 3. Quality of Family life & 83.54 & 22.25 & & & $.38^{* *}$ & $-.53^{* *}$ \\
\hline 4. Perceived competence & 30.08 & 4.87 & & & 1 & $-.25^{* *}$ \\
\hline 5. Deviant behaviour & 44.81 & 21.43 & & & & 1 \\
\hline
\end{tabular}

Notes: $* p<.05, * * p<.01, N=384$.

\section{Hypothesis two}

Baron and Kenny (1986) recommended the use of a fourstep multiple regression approach in a mediation study in which several regression analyses were conducted and the significance of the coefficients were examined at each step. In the first model, workplace deviance was regressed on quality of family life. In the second model, perceived competence was regressed on the quality of family life. At the third level, workplace deviance was regressed on perceived competence. Lastly, in the fourth model, the predictor (quality of family life) and mediating variables (perceived competence) were entered simultaneously into the equation to determine whether the introduction of the mediating variable (perceived competence) would influence the initial link between the quality of family life and workplace deviance.

Figure 3 shows a simple mediation model of workplace deviance behaviour by university employees. In Model 1 of Table 2, workplace deviance was regressed on the quality of family life. The result revealed that the quality of family life explained a significant $29 \%$ variance in the prediction of work deviant behaviour $\left(\mathrm{R}^{2}=0.29, \mathrm{~F}(1,382)\right.$ $=154.10, \mathrm{p}<0.01)$. The quality of family life has significant independent predictors on workplace deviant behaviour $(\beta=-0.52, t=-12.45, p<0.01)$. This indicates that when employees' quality of family life goes up by 1 standard 
Figure 3. Simple mediation model of workplace deviant behaviour

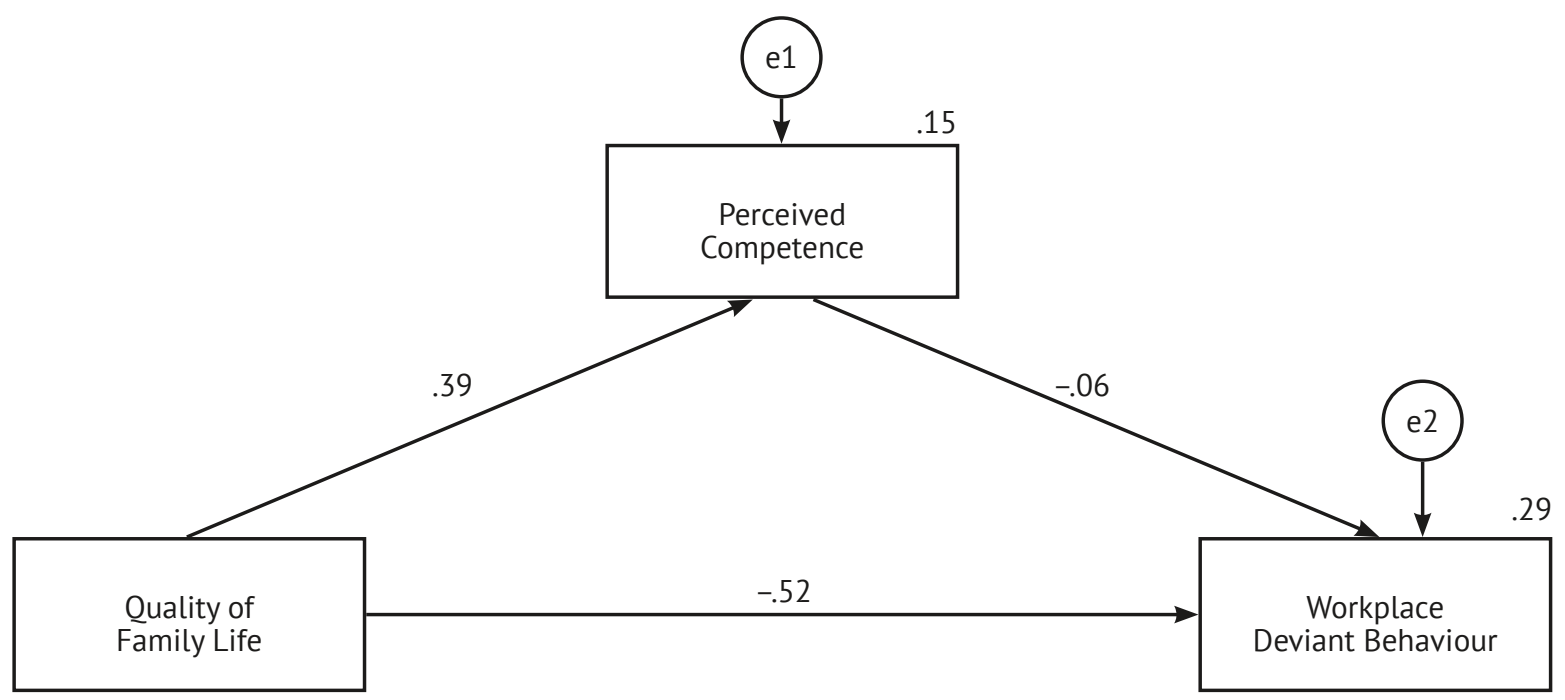

Table 2. Hierarchical multiple regression of mediating effect of perceived competence on quality of family life and workplace deviant behaviour

\begin{tabular}{|c|c|c|c|c|c|c|c|c|}
\hline & $\mathrm{R}$ & $\mathrm{R}^{2}$ & $\mathrm{~F}$ & B & SE & $\beta$ & $\mathrm{t}$ & $p$ \\
\hline \multirow[t]{2}{*}{ Quality of family life $\rightarrow$ Workplace deviant behaviour } & 0.54 & 0.29 & 154.10 & & & & & \\
\hline & & & & -0.54 & 0.04 & -0.52 & -12.45 & $<0.001$ \\
\hline \multirow[t]{2}{*}{ Quality of family life $\rightarrow$ Perceived competence } & 0.39 & 0.15 & 66.50 & & & & & \\
\hline & & & & 0.08 & 0.01 & 0.39 & 8.16 & $<0.001$ \\
\hline \multirow[t]{2}{*}{ Perceived competence $\rightarrow$ Workplace deviant behaviour } & 0.26 & 0.07 & 26.79 & & & & & \\
\hline & & & & -1.13 & 0.22 & -0.26 & -5.18 & $<0.001$ \\
\hline $\begin{array}{l}\text { Quality of family life \& Perceived competence } \rightarrow \text { Work deviant } \\
\text { behaviour) }\end{array}$ & 0.54 & 0.29 & 78.37 & & & & & \\
\hline Quality of family life & & & & -0.50 & 0.05 & -0.51 & -.11 .02 & $<0.001$ \\
\hline Perceived competence & & & & -0.25 & 0.21 & -0.06 & -5.23 & $<0.001$ \\
\hline Test Statistic & $p$ & & & & & & & \\
\hline 3.23798285 & $<0.05$ & & & & & & & \\
\hline
\end{tabular}

deviation, workplace deviant behaviour reduces by 0.52 standard deviations (as the quality of family life improves, workplace deviant behaviour reduces).

The result in the second model revealed that the quality of family life explained a significant $15 \%$ variance in relationship with perceived competence $\left(\mathrm{R}^{2}=0.15, \mathrm{~F}(1,382)\right.$ $=66.50, \mathrm{p}<0.01)$. More important, the quality of family life significantly influences perceived competence $(\beta=0.39$, $\mathrm{t}=8.16, \mathrm{p}<0.01)$. This indicates that when employees' quality of family life goes up by 1 standard deviation, perceived competence of the employee improves by 0.39 standard deviations, meaning that improvement in the quality of family life of the employees leads to an enhanced sense of competence in the employees.

The third model revealed that perceived competence, which is the mediating variable, significantly predicted workplace deviant behaviour $\left(\mathrm{R}^{2}=0.07, \mathrm{~F}(1,382)=26.76, \mathrm{p}<0.01\right)$. It was further revealed that perceived competence $(\beta=$ $0.26, \mathrm{t}=-5.18, \mathrm{p}<0.01$ ) has a significant direct influence on workplace deviant behaviour. This implies that an increase in perceived competence leads to a decrease in workplace deviant behaviour. 
In the final model, the predictor (quality of family life) and mediator (perceived competence) were simultaneously entered into the equation. The mediator (perceived competence) significantly mediates the relationship between the quality of family life and workplace deviance $(\beta=-0.06$; $\mathrm{p}<0.01)$. The inclusion of perceived competence in the fourth model reduces the beta $(\beta)$ value of the link between the quality of family life and workplace deviance from -0.54 to -0.06 .

Furthermore, a Sobel test was conducted to determine the mediating effect of perceived competence on quality of family life-workplace deviant behaviour, since Baron and Kenny's (1986) analytical approach did not provide enough information on the mediating role of perceived competence in quality of family life-workplace deviant behaviour, but only indicated that mediation of perceived competence is possible.

The Sobel test revealed that perceived competence mediates the relationship between the quality of family life and workplace deviance behaviour $(\mathrm{z}=3.23$; $\mathrm{p}=<0.05)$. The second hypothesis was also accepted.

\section{Discussion}

The current study examined the mediating role of perceived competence in the relationship between the quality of family life and workplace deviant behaviour among university staff in Nigeria. The first hypothesis revealed that there was a significant negative relationship between quality of life and workplace deviant behaviour, suggesting that university staff who perceived high quality of life showed a low tendency to engage in workplace deviant behaviour. The finding was also in line with Ferguson (2012), who investigated the influence of family conflict on deviant behaviour. The result showed a negative association between family conflict and deviance. The study finding was also in line with Shakir and Siddiqui (2014), who found that work-life balance, except personal commitment, has a significant influence on deviant workplace behaviour. The reason for this finding may beconnected to the attention that employees give to their family life. Culturally, in Nigeria as well as conventional wisdom, the family are always vital and an integral part of individual well-being. Employees are always happy when their families are happy because oftentimes, the family is what employees fall back to when challenges or problems arise. This reality even makes the quality of family life important. Employees who are happy with the present state of their family often engage in positive behaviour at work, because they tend to be happy, fulfilled and ready to work for the goal of the organisation and not engaging in behaviours that deviate from the university standard. Theoretically, the wellness model (Adams, Bezner \& Steinhardt, 1997) also supports the finding of this present study, as it postulates that employees who are satisfied with their family wellness would not engage in deviant behaviour.

The second result supports the hypothesized mediation of the relationship between the quality of family life and workplace deviant behaviour, indicating that perceived competence partially mediates the relationship between the quality of family life and workplace deviant behaviour. This implies that university staff twho have the confidence that they can handle most situations will make their family happy and satisfied at any point in time without necessarily resorting to any form of deviant behaviour. The finding agreed with that of Abas, Omar, Halim and Hafidz (2015), who found that organisational-based self-esteem mediates the relationship between perceived organisational support and counterproductive work behaviour. The study finding was also similar to that of Ferris Brown, Lian, and Keeping (2009), who found that organisational-based self-esteem mediates the relationship between perceived organisational support and counterproductive work behaviour. The reason for this finding could be because employees in Nigeria are often employed by bias or through favouritism, without considering if they are competent for the job. Any monor challenges, such as family challenges, may make make such employees engage in deviant behaviour as a result of their incompetence. One possible explanation for the finding was offered by self-determination theory (Deci \& Ryan, 1985), which proposed that individuals who believe in their ability are often determined to engage in any roles. Therefore, university employees who believe in their ability often handle their family well-being in a way that satisfies them without triggering any negative behaviour at work.

\section{Theoretical and practical implications}

Based on the findings of the present study, we concluded that quality of life not only has a negative relationship with workplace deviant behaviour but also an indirect relationship with workplace deviant behaviour through perceived competence. Though the mediation hypothesis is partially supported, it is suggested that when university staff have the belief and confidence to handle their family well-being, they tend to be happy and satisfied, which, in turn, decreases their tendency to engage in any form of deviant behaviour. Our study findings revealed important implications for theory and practice. Theoretically, the findings lend support to and also highlight the importance of using the wellness model (Adams, Bezner \& Steinhardt, 1997) and self-determination theory (Deci \& Ryan, 1985) to explain the dynamic relationship between perceived competence, quality of life and 
work deviant behaviour among university staff. In terms of practical implications, the finding can provide university management with greater insight on the role of quality of family life on deviant behaviour among university staff. It, therefore, means that university management should implement an appropriate family programme and policies for its staff. The result also has a practical implication for managers to formulate intervention aimed at improving competence among university staff such that it will enable them to have the skill to maintain their family life, which, in turn, will decrease their likelihood of engaging in the deviant act.

Given these practical implications, we, therefore, recommend that university management should implement policies meant to improve the quality of family life. Policies such as flexible work scheduling, implementation of family leave, and family support programmes could serve as a buffer for employees to improve their family life which, will reduce their engagement in deviant behaviour. Also, psychologists should develop a psychological test at the recruitment level aimed at identifying the potential employee who is highly competent on the job, while for staff who are already on the job, frequent training and competence skill programmes can be put in place to improve and enhance their sense of competence, so that this category of individuals will have the capacity and skill to manage their family well-being, which will decrease their likelihood of engaging in deviant behaviour.

\section{Limitations and suggestions for future studies}

Despite the rich contribution of this study to literature, it is still faced with some limitations. First, the data were obtained from four universities' employees. Therefore, its findings may not be generalisable to other universities employees in Nigeria. Another limitation of the study is the inability to get quality of life studies; instead, the researchers relied on work-life conflict studies. Future studies can also increase the sample size for more valid generalization. More empirical studies should be conducted on the quality of family life on work deviant behaviour using a different set of employees in different settings. Finally, a more improved method of data collection such as focus group discussion and interview can also be incorporated by future researchers.

\section{Acknowledgement}

The authors of this study will like to acknowledge the university staff members who took their precious time to participate in this important study.

\section{Declaration of interest statement}

The authors in this study declare no conflict of interest.

\section{References}

Abas, C., Omar, F., Halim, W., \& Hafidz, M. (2015). The Mediating Role of Organisational-Based Self-Esteem in Perceived Organisational Support and Counterproductive Work Behaviour Relationship. International Journal of Business and Management,10(9), 99-108. https://doi.org/10.5539/ijbm.v10n9p99

Adams, T., Bezner J., \& Steinhardt, M. (1997). The conceptualization and measurement of perceived wellness: Integrating balance across and within dimensions. American Journal of Health Promotion, 11, 208-218. https://doi.org/10.4278/0890-1171-11.3.208

Ajala E. (2017). Work-family-conflict and family-work-conflict as correlates of job performance among working mothers: implications for industrial social workers. African Journal of Social Work, AJSW, 7(1), 52-62.

Bajo, P. F. (2005). Influence of sense of competence and need for achievement on job commitment of employees (A case study of N.S.T.I.F). An Unpublished MMP Project submitted to the Department of Psychology, University of Ibadan, Nigeria.

Balogun, A. G., Esan, F.O., Ezeugwu, C. R., \& Orifa, E. I. (2016) 'Mediating Effect of Job Satisfaction on Psychological Contract Breach and Workplace deviance among Police Personnel. Practicum Psychologia, 6, 14-31.

Balogun, A. G. (2017). Emotional intelligence as a moderator between perceived organisational injustice and organisational deviance among public sector employées. International Journal Management Practice, 10(2), 175-188. https://doi.org/10.1504/JJMP.2017.083084

Balogun, S. K., Ojedokun, O. A., \& Tijani F. A.(2012). Self-Esteem and achievement motivation as predictors of perceived sense of competence among workers in a Nigerian university teaching hospital. African Research Review Serial, 25, 36-54. https://doi. org/10.4314/afrrev.v6i2.4

Baron, R.M., \& Kenny,D.A.(1986). The moderator-mediator variable distinction in social psychological research: conceptual, strategic, and statistical considerations. Journal of Personality and Social Psychology, 51, 1173-1182. https://doi.org/10.1037/0022-3514.51.6.1173

Beach Center on Disability (2012) 'The Family Quality of Life Scale (FQOL). Measurement Instrument Database for the Social Science. Retrieved from http://www.midss.org/sites/default/files/fqol_survey.pdf

Bennett, R. J., \& Robinson, S. L. (2000). Development of a measure of workplace deviance. Journal of Applied Psychology, 85(3), 349 -360. https://doi.org/10.1037/0021-9010.85.3.349

Bennett, J., \& Robison, S. (2003). A Typology of Deviant Workplace Behaviours: A Multidimensional Scaling Study. The Academy of Management Journal, 38(2), 555-572. 
Dare A. Fagbenro, Mathew O. Olasupo: Quality of Family Life and Workplace Deviant Behaviour with Perceived Competence as a Mediator among University Staff

Bennett, L., \& Amyx, P. (2013). Work-family conflict as a primary antecedent of salesperson deviance. Journal of Family, 2(7), 13-34.

Boyatzis, R. E. (2008). The competent manager: A model for effective performance. NY: John Wiley \& Sons.

Caroline, U. N. (2015). Absenteeism, favoritism, and tardiness as predictors of job deviance in academia: The Nigeria experience. Journal of Social Sciences and Humanities, 1(2), 75-81.

Chernyak-Hai, L., Kim, K., \& Tziner, A. (2019). Relationships between workplace deviance interacted with gender and marital status: The correspondence analysis approach. Psychological Reports, 122(4), 1494-1515. https://doi.org/10.1177/0033294118783500

Chiamaka, J.A., Tochukwu, O., \& Kizito, O. (2015). Impact of emotional intelligence and job boredom proneness on counterproductive work behaviour. Advances in Applied Psychology, 1(2), 101-106.

Chirasha, V., \& Mahapa, M. (2012). An analysis of the causes and impact of deviant behaviour in the workplace. The case of secretaries in state universities. Emerging Trends in Economics and Management Sciences (JETEMS), 3(5), 415-421.

Darrat, M. (2010). An investigation into the effects of work-family conflict and job satisfaction on salesperson deviance. Journal of Personal Selling \& Sales Management, 3(3), 239-251. https://doi.org/10.2753/PSS0885-3134300304

Deci, E. L., \& Ryan, R. M. (2001). Human autonomy: The basis for true self-esteem. In M. Kernis (Ed.), Efficacy, agency, and self-esteem pp. 31-49. New York: Plenum. https://doi.org/10.1007/978-1-4899-1280-0_3

Dewanga, R., \& Verghese, M. (2018). Predictors of workplace deviant behaviour. International Journal of Academic Research and Development, 3(2), 974-977.

Dutcher, L. A., \& Adam, C. E. (1994). Work environment perception of staff nurses and aids in home health agencies. Journal of Nursing Administration, 24(10), 24-30. https://doi.org/10.1097/00005110-199410000-00007

Everton, W.J., Jolton, J. A., \& Mastrangelo, P. M (2007). Be nice and fair or else: Understanding reasons for employees' deviant behaviourJournal of Management Development, 26(2), 117-131. https://doi.org/10.1108/02621710710726035

Fadli, E. (2012). Psychological factors and work deviant behaviour. Journal of Education, 3, 45-57.

Fagbohungbe, B. O., Akinbode, G. A., \& Ayodeji, F. (2012). Organisational determinants of workplace deviant behaviours: An empirical analysis in Nigeria. International Journal of Business \& Management, 7(5), 207-221. https://doi.org/10.5539/ijbm.v7n5p207

Ferguson, T., Carlson, P., \& Whitten, E. (2012). A two-study examination of work-family conflict, production deviance and gender. Journal of Work Behaviour, (5), 35-76.

Ferris, D. L., Brown, D. J., Lian, H., \& Keeping, L. M. (2009). When does self-esteem relate to deviant behaviour? The role of contingencies of self-worth. Journal of Applied Psychology, 94(5), 1345-1353. http://dx.doi.org/10.1037/a0016115

Harter, S. (1990). Causes, correlates, and the functional role of global self-worth: A life-span perspective. In R. J. Sternberg \& J. Kolligan, Jr. (Eds.), Competence considered pp.67-97. New Heaven, CT: Yale University Press.

Hollinger, R. C. (2011). 2010 national retail security survey executive summary. Loss Prevention Magazine, 1 December 2011. Retrieved from https://losspreventionmedia.com/2010-national-retail-security-survey-executive-summary/

$\mathrm{Hu}$, X., Summers, J. A., Turnbull, A., \& Zuna, N. (2011). The quantitative measurement of family quality of life: A review of available instruments. Journal of Intellectual Disability Research, 55,(12), 1098-1114. https://doi.org/10.1111/j.1365-2788.2011.01463.x

Igbe, J. E., Okpa, J. T., \& Aniah, E. A. (2017). Working conditions and deviant behaviour of employees in the University of Calabar, Cross River State, Nigeria. IOSR Journal of Humanities and Social Science, 22(7), 74-83.

Kinnunen, U., Geurts, S., \& Mauno, S. (2004).Work-to-family conflict and its relationship with satisfaction and well-being: a one-year longitudinal study on gender differences. Work and Stress, 18(1), 1-22. https://doi.org/10.1080/02678370410001682005

Krejcie, R. V., \& Morgan, D. W. (1970). Determining sample size for research activities. Educational and Psychological Measurement, 30 , 607-610. https://doi.org/10.1177/001316447003000308

Krischer M. (2010). Can counterproductive work behaviours be productive? CWB as emotion-focused coping. Journal of Occupational Health Psychology, 15(2), 154-166. https://doi.org/10.1037/a0018349

Laschinger, H. K., Wong, C., McMahon, L., \& Kaufmann, C. (1999). Leader behaviour impact on staff nurse empowerment, job tension, and work effectiveness. Journal of Nursing Administration, 29(5), 28-39. https://doi.org/10.1097/00005110-199905000-00005

Li, J. (2015). Perceived Competence, Autonomy, and Subjective Happiness: The Mediating Role of Job Crafting. Osaka economic journal, 64(4), 92-104

Malisetty, D., \& Kumari, K. (2016). An Investigation on relationship of deviance workplace behaviour with organisational justice, abusive supervision and work-family conflict. Indian Journal of Science and Technology, 3, 77-81.

Masterpasqua, F. (2010). A competence paradigm for psychological practice. American Psychologist, 44, 1366-1371. https://doi. org/10.1037/0003-066X.44.11.1366

Manani, E., \& Ngui, K. (2019). Effects of employee competencies on employee job performance in humanitarian organizations. A case study of the world food programme, Kenya 7(10), 1688-1702

Moti, U. G. (2010). Employee misbehaviour and management among academic and non-academic staff of the University of Abuja, Nigeria Retrieved from https://www.researchgate.net/publication/333248030_employee_misbehaviour_and_management_among_ academic_and_non-academic_staff_of_the_university_of_abuja_nigeria

Olabimitan, B., \& Alausa, W. M. (2014).Psychological factors predicting workplace deviance behaviour among nurses in the public health sector in Lagos. Nigerian Journal of Applied Behavioural Sciences, 2, 137-152.

Olasupo, M. O., \& Fagbenro, D. A. (2018). Perceived competence, discrimination and deviant behaviour among university employees: A mediating study. African Journal for Psychological Studies of Social Issues, 21(3), 24-36. 
Omar, F., Halim, F. W., Zainah, A. Z., Farhadi, H., Nasir, R., \& Khairudin, R. (2011). Stress and job satisfaction as antecedents of workplace deviant behaviour. World Applied Sciences Journal, 12, 46-51.

Rahman, S., Karan, K., \& Shameem, D.(2013).Relationship between competence and typology of deviant workplace behaviour. NIDA Development Journal, 53, 2-20.

Ratnasari, S., \& Adam, G. (2019). The Contribution of Competence, Motivation, And Creativity Towards Teacher's Performance Through Work Satisfaction. International Journal of Engineering and Advanced Technology (IJEAT), 8(5), 145-149. https://doi.org/10.35940/ijeat. E1021.0585C19

Robinson, S. L., \& Bennett, R.J. (1995). A typology of deviant workplace behaviours: A multidimensional scaling study. Academy of Management Journal, 38(2), 555-572.

Roy, L., Bastounis, M. \& Minibas-Poussard, J. (2012). Interactional justice and counterproductive work behaviour: The Mediating role of negative emotions. Social behaviour and personality, Journal of behaviour, 40(8), 1341-1356. https://doi.org/10.2224/ sbp.2012.40.8.1341

Rubab, U. (2017). Impact of work family conflict on burnout and workplace deviant behaviour: mediating role of stress. Jinnah Business Review, 5(1), 1-10.

Saad, N. A., Yahya, K. K., \& Yean, T. F. (2016). Does workplace deviant behaviour influence generation perception?. International Journal of Humanities and Social Science, 6(3), $104-111$.

Shakir, K., \& Siddiqui, S. (2014). The impact of work-life balance policies on deviant workplace behaviour in Pakistan. International Journal of Economics, Commerce and Management United Kingdom, 2, 6-41. https://doi.org/10.2139/ssrn.2462283

Shamsudin, M., Subramaniam, C., \& Ibrahim, H. (2011). HR practices and deviant behaviour at work: An Exploratory Study. 2011 International Conference on Business and Economics Research. International Proceedings of Economics Development and Research, 16, $13-17$. Retrieved from http://www.ipedr.com/list-41-1.html

Snyder, R.A., \& Bruning, N.S. (1999). Sex differences in perceived competence: an across organisations study. Administration in Social Work, 3(3), 349-358. https://doi.org/10.1300/J147v03n03_08

Snyder, R. A., \& Morris, J. H. (1978). Reliability of the factor structure of the Wagner and Morse Competence Index. Psychological Reports, 43(2), 419-425. https://doi.org/10.2466/pr0.1978.43.2.419

Suleiman, W. (2013). A study of causes of poor attitude to work among workers of both public and private sectors organisations in Bauchi State-Nigeria. International Journal of Academic Research in Business and Social Sciences, 3(7), 143-152. https://doi.org/10.6007/ IJARBSS/v3-i7/16

Thau, S., Aquino, K., \& Wittek, R. (2007). An extension of uncertainty management theory to the self: The relationship between justice, social comparison orientation, and antisocial work behaviours. Journal of Applied Psychology, 92, 250-258. https://doi. org/10.1037/0021-9010.92.1.250

Ulrich, T. (1998). Family life and deviance among selected employees. An International Journal of Police Strategies and Management, 27, 380-395.

Wagner, F.R., \& Morse,J.J.(1975).A measure of Individual sense of competence. Psychological Report, 36, 451-459.https://doi.org/10.2466/ pr0.1975.36.2.451

White, R.W. (2001). Motivation reconsidered: The concept of competence. Psychological Review, 66, 297-333. https://doi.org/10.1037/ h0040934

Willness, C. R., Steel, P., \& Lee, K. (2007). A meta-analysis of the antecedents and consequences of workplace sexual harassment. Personnel Psychology, 60(1), 127-162. https://doi.org/10.1111/j.1744-6570.2007.00067.x

Wu, R.(2010). Psychological Contract and Its Motivational competency. Journal of Managerial Psychology, 25, 4 -21.

Zuna, N., Summers, J. A., Turnbull, A. P., \& Hu, X. (2012). Theorizing about family quality of life. In R. Kober (Ed.), Enhancing the Quality of Life of People with Intellectual Disability. From Theory to Practice pp. 241-278. New York: Springer. https://doi.org/10.1007/978-90481-9650-0_15 


\section{Kakovost družinskega življenja in odklonsko vedenje na delovnem mestu z zaznano kompetentnostjo kot posrednikom med osebjem na univerzi}

\section{Izvleček}

Več študij je ugotovilo različne dejavnike kot predhodnike odklonskega vedenja, vendar je o vlogi kakovosti družinskega življenja v smislu odklonskega vedenja na delovnem mestu in o vlogi zaznane kompetentnosti kot posrednika med kakovostjo družinskega življenja in odklonskim vedenjem v literaturi še vedno malo napisanega. Študija preučuje posredniški učinek zaznane kompetentnosti na odnos med kakovostjo družinskega življenja in odklonskim vedenjem na delu. Študija je kot teoretski izhodišči uporabila model dobrega počutja in teorijo samoodločanja. V študiji je sodelovalo 384 oseb, zaposlenih na univerzi v Nigeriji. Rezultati so pokazali, da obstaja pomembno negativno razmerje med kakovostjo družinskega življenja in odklonskim vedenjem na delovnem mestu. Rezultati hierarhične multiple regresije so prav tako pokazali, da zaznana kompetentnost deluje kot posrednik med kakovostjo družinskega življenja in odklonskim vedenjem na delovnem mestu. Te ugotovitve nakazujejo, da bi morali psihologi oblikovati programe usposabljanja, ki so usmerjeni v izboljšanje občutka kompetentnosti in kakovosti družinskega življenja, kar bo neizogibno zmanjšalo odklonsko vedenje na delovnem mestu.

Ključne besede: kakovost družinskega življenja, zaznana kompetentnost, odklonsko vedenje na delovnem mestu, zaposleni na univerzi 